\title{
Radioactive phosphorus uptake testing of choroidal lesions A report of two false-negative tests
}

\author{
DENNIS M. ROBERTSON \\ From the Department of Ophthalmology, Mayo Clinic and Mayo Foundation
}

The purpose of this report is to review the ${ }^{32} \mathrm{P}$ radioisotope uptake test as it relates to experiences with the diagnosis of suspected malignancies of the eye and to report two false-negative studies that were recorded over the posterior sclera of two eyes harbouring malignant melanomas of the choroid.

\section{Method and materials}

${ }^{32} \mathrm{P}$ testing for suspected ocular malignancy has been performed during the past three years at the Mayo Clinic in a manner similar to that described by Shields, Sarin, Federman, Mensheha-Manhart, and Carmichael (1974). Until recently our technique differed, however, in that we administered the ${ }^{32} \mathrm{P}$ orally rather than intravenously. A dose of $750 \mu \mathrm{Ci}$ of ${ }^{32} \mathrm{P}$ was given to the patient orally on an empty stomach two to six days before testing, as suggested by Ruiz and Howerton (1975). The Gass marker is used for localizing the boundaries of the suspected tumour to the scleral surface (Gass, 1966). Radioactive counts are then recorded alternately over the tumour site and at a specifically marked control site usually situated on the opposite side of the globe. We use the radioactivity detection probe and scaler (Ruiz, 1972).* Four measurements are generally recorded over each site, although more are taken if there is inconsistency in counts or if the differences between counts over control and tumour site are not obviously disparate. The percentage uptake is then determined by the formula: percentagr difference $=\left(\mathrm{C}_{t}-\mathrm{C}_{\mathrm{c}}\right) / \mathrm{C}_{\mathrm{c}} \times 100$, in which $\mathrm{C}_{t}$ is the average count over the suspected lesion and $\mathrm{C}_{\mathrm{c}}$ is the average count over the control site. We consider that the test is positive if the percentage uptake over the tumour is at least 75 per cent greater than that over the control site.

\section{Report of cases}

CASE I

A 72-year-old woman was referred with a retinal detachment in the left eye which was associated with an underlying mass located in the superior portion of the globe. Visual acuity was $20 / 20$ in the right eye and 20/100 minus in the left. A non-rhegmatogenous retinal

*Manufactured by EON Corporation, Brooklyn, New York.

Address for reprints: Dennis M. Robertson, MD, 200 First Street SW, Rochester, Minnesota 5.5901, USA detachment was present, under which a raised relatively amelanotic lesion could be seen (Fig. I $a$ ). The clinical findings indicated the diagnosis of a primary malignant melanoma of the choroid. A general medical examination did not reveal evidence of metastasis or a primary tumour elsewhere than in the eye. A total of $750 \mu \mathrm{Ci}$ of ${ }^{32} \mathrm{P}$ was given orally in anticipation of radioisotope testing. Three days later, the patient developed ocular pain accompanied by chemosis, congestion, and orbital swelling. Grade 2 flare and cells were present in the anterior chamber, and the vitreous contained blood originating from a haemorrhage within the tumour. Three days later (six days after receiving oral ${ }^{32} \mathrm{P}$ ), a radioactive phosphorus uptake study was performed while the patient was under general anaesthesia. In spite of the vitreous haemorrhage, it was not difficult to locate the tumour and determine placement of the radioactivity detection probe (Fig. $\mathrm{I} b$ and Table I). Although the uptake study was only 60 per cent greater over the tumour site compared with the control, the clinical findings so strongly indicated primary malignant melanoma that the eye was removed. No evidence of extraocular tumour extension was recognized to account for the recent orbital inflammation.

Histological sections demonstrated a large necrotic malignant melanoma of the choroid without evidence of extrascleral extension. Haemorrhagic choroidal detachments present in some areas caused significant thickening of the choroidal layer (Fig. Ic).

CASE 2

A 66-year-old woman was seen in the eye department in August 1973 with a large, raised, choroidal mass in

Table I Radioactive counts from tumour and control sites in Case I (see Fig. I)

\begin{tabular}{|c|c|c|c|c|}
\hline Counts & Site & Counts/minute & Average & $\begin{array}{l}\text { Percentage uptake } \\
\qquad=\frac{C_{t}-C_{c}}{C_{c}} \times 100\end{array}$ \\
\hline $\begin{array}{l}\text { Tumour } \\
\left(C_{t}\right)\end{array}$ & $\begin{array}{l}\text { A } \\
\text { B } \\
\text { C } \\
\text { D }\end{array}$ & $\begin{array}{l}72,82,90,71 \\
65,85,98,105 \\
69 \\
55,60,65\end{array}$ & $\begin{array}{l}79 \\
88 \\
69 \\
59\end{array}$ & $\begin{array}{l}\text { Averaging all counts: } \\
\text { uptake }=25 \text { per cent }\end{array}$ \\
\hline $\begin{array}{l}\text { Control } \\
\left(\mathrm{C}_{\mathrm{c}}\right)\end{array}$ & $\begin{array}{l}\text { IN } \\
\text { IT }\end{array}$ & $\begin{array}{l}53,58,51,59 \\
57,72,79,6 \text { I }\end{array}$ & $\begin{array}{l}55 \\
67\end{array}$ & $\begin{array}{l}\text { Highest average tumour } \\
\text { count and lowest } \\
\text { average control count } \\
\text { uptake }=60 \text { per cent }\end{array}$ \\
\hline
\end{tabular}




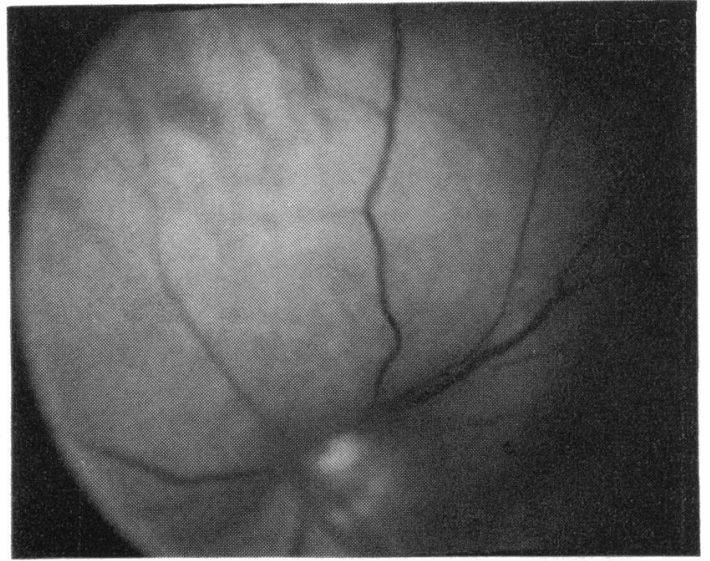

(

FIG. I (Case I) (a) Fundus showing choroidal malignant melanoma superior to optic disc. Photograph taken six days before ${ }^{32} P$ testing. (b) Diagram showing clinical extent of choroidal tumour (hatched) and extent of secondary retinal detachment (shaded). Labelled areas are sites of ${ }^{32} P$ testing (see Table I). (c) Cross-section of eye containing necrotic malignant melanoma of choroid. Haemorrhagic choroidal detachment can be seen extending anteriorly from both sides of the tumour

the superior portion of the left eye which was thought most likely to represent a primary malignant melanoma (Fig. 2a). Past records showed that a retinal detachment had been recognized in the fellow eye 13 years earlier and that there had been choroidal pigmentation in the superior nasal fundus of the left eye six years previously.

Table II Radioactive counts from tumour and control sites in Case 2 (see Fig. 2)

\begin{tabular}{|c|c|c|c|c|}
\hline Counts & Site & Counts/minute & Average & $\begin{array}{l}\text { Percentage uptuke } \\
\qquad=\frac{C_{t}-C_{c}}{C_{c}} \times 100\end{array}$ \\
\hline $\begin{array}{l}\text { August I } \\
\text { Tumour } \\
\left(\mathrm{C}_{\mathrm{t}}\right)\end{array}$ & $\begin{array}{l}973 \\
\text { A } \\
\text { B } \\
\text { C } \\
\text { D }\end{array}$ & $\begin{array}{l}168,169,165 \\
193,167,185 \\
150,141,155 \\
155\end{array}$ & $\begin{array}{l}167 \\
182 \\
149 \\
155\end{array}$ & $\begin{array}{l}\text { Averaging all counts: } \\
\text { uptake }=18 \text { per cent }\end{array}$ \\
\hline $\begin{array}{l}\text { Control } \\
\left(\mathrm{C}_{\mathrm{c}}\right)\end{array}$ & $\begin{array}{l}\text { IN } \\
\text { IT }\end{array}$ & $\begin{array}{l}\text { I } 34,145,138 \\
150,139, \text { I } 32\end{array}$ & $\begin{array}{l}139 \\
140\end{array}$ & $\begin{array}{l}\text { Highest average tumour } \\
\text { count and lowest } \\
\text { average control count } \\
\text { uptake }=3 \mathrm{I} \text { per cent }\end{array}$ \\
\hline $\begin{array}{l}\text { April 19 } \\
\text { Tumour }\end{array}$ & $\begin{array}{l}74 \\
\text { Random } \\
\text { over } \\
\text { tumour } \\
\text { A }\end{array}$ & $\begin{array}{l}\text { n } \\
245,198,335 \\
387,396,371\end{array}$ & $\begin{array}{l}259 \\
385\end{array}$ & $\begin{array}{l}\text { Averaging all counts: } \\
\text { uptake }=250 \text { per cent }\end{array}$ \\
\hline Control & IN & $\begin{array}{l}90,92,93 \\
86,108,85\end{array}$ & $\begin{array}{l}92 \\
93\end{array}$ & $\begin{array}{l}\text { Highest average tumour } \\
\text { count and lowest } \\
\text { average control count } \\
\text { uptake }=318 \text { per cent }\end{array}$ \\
\hline
\end{tabular}
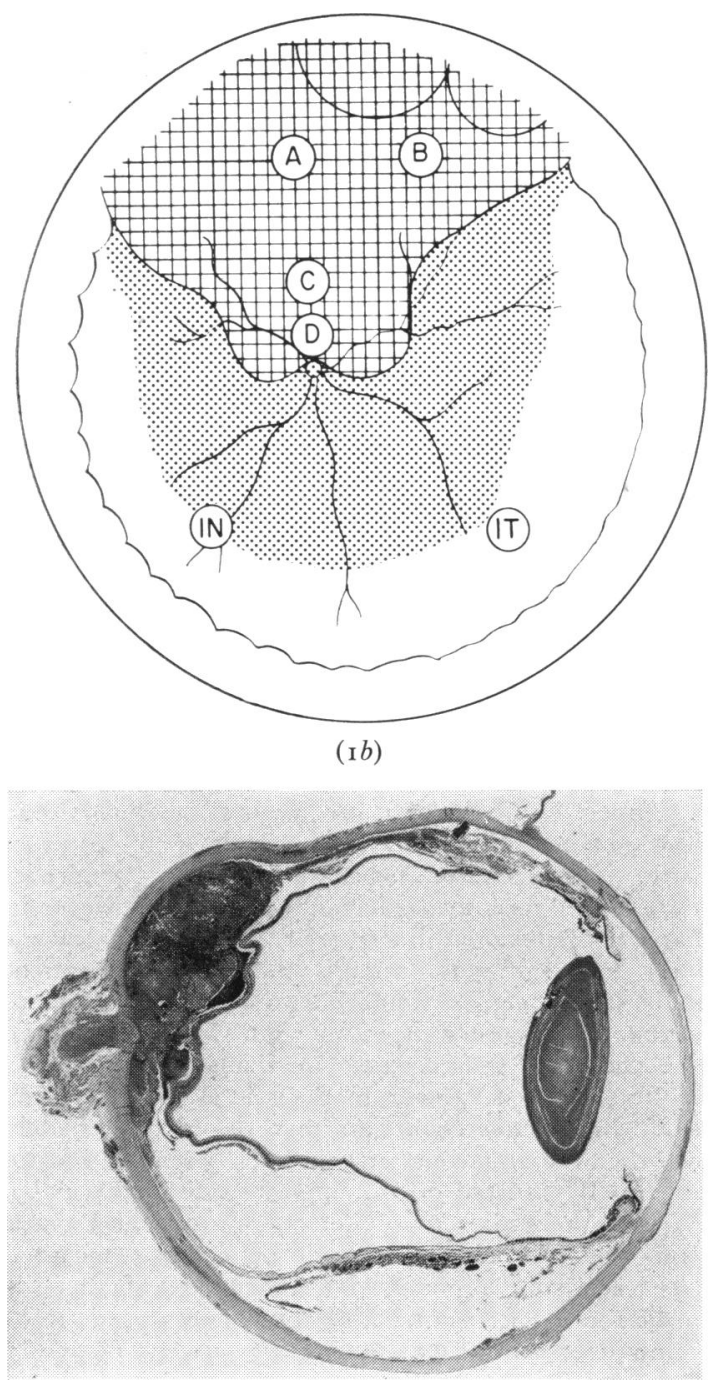

( Ic)

Past medical history revealed that the patient had had three primary non-ocular carcinomas all managed at the Mayo Clinic during the preceding 17 years. These were a grade I Hurthle cell adenocarcinoma of the thyroid, a grade 3 adenocarcinoma of the left breast, and at a later date a grade 3 scirrhous carcinoma of the remaining breast.

A radioactive phosphorus uptake study was done over the tumour in the left eye in August 1973, 48 hours after the patient received $750 \mu \mathrm{Ci}$ of ${ }^{32} \mathrm{P}$ orally (Fig. $2 b$ and Table II). The test was interpreted as being negative. Although our clinical impression remained strong that the eye contained a malignant melanoma, the eye was not removed. In anticipation of possibly removing the eye at some future date, the fellow eye with the longstanding retinal detachment was treated with a scleral buckling procedure. Although anatomic reattachment was achieved, the visual acuity was not 


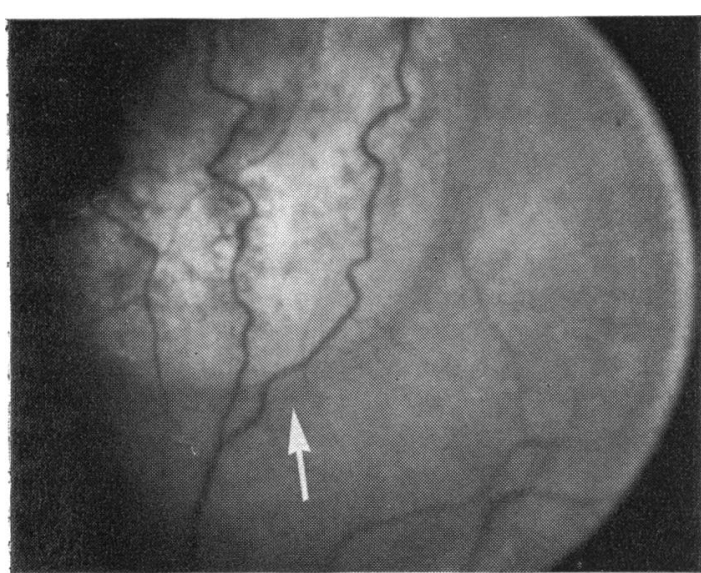

$(2 a)$

FIG. 2 (Case 2) (a) Fundus showing most inferior extent of choroidal malignant melanoma (arrozv) located superior to disc. (b) Diagram showing approximate clinical extent of choroidal tumour (hatched) and extent of secondary retinal detachment (shaded). Labelled areas are sites of ${ }^{32} P$ testing (see Table II). (c) Fundus showing expansion of tumour (arrow). (Taken eight months after Fig. 2a)

improved beyond counting fingers. During the ensuing months, tumour growth was substantiated with photographs (Fig. 2c). In April 1974, a radioactive phosphorus uptake study was repeated, and the result was unequivocally positive (Table II).

The poor vision in the fellow eye, the $20 / 20$ vision in the eye containing the tumour, the age of the patient, and the history of three previously documented nonocular primary carcinomas were factors that led to a decision to consider a trial of radiation therapy. A dose of 4000 rads was given to the lesion in divided doses during a 15-day period. Although the appearance of the tumour had changed little, vision failed seven months after irradiation because of intraocular haemorrhage, and in November 1974 the eye was removed. Histological sections confirmed the clinical impression of malignant choroidal melanoma (epithelioid and spindle B-cell type).

\section{Discussion}

The ${ }^{32} \mathrm{P}$ test, which fell into disrepute in the r950s, has again gained popularity since the development of more sophisticated and more practical instrumentation. The testing technique itself, while demanding meticulous care in the manner of probe placement, is well suited for the retinal surgeon who is accustomed to doing scleral buckling procedures which require precise localizing techniques. Proper interpretation of the test is dependent on accurate localization of the tumour to the scleral surface, just as proper management of a retinal
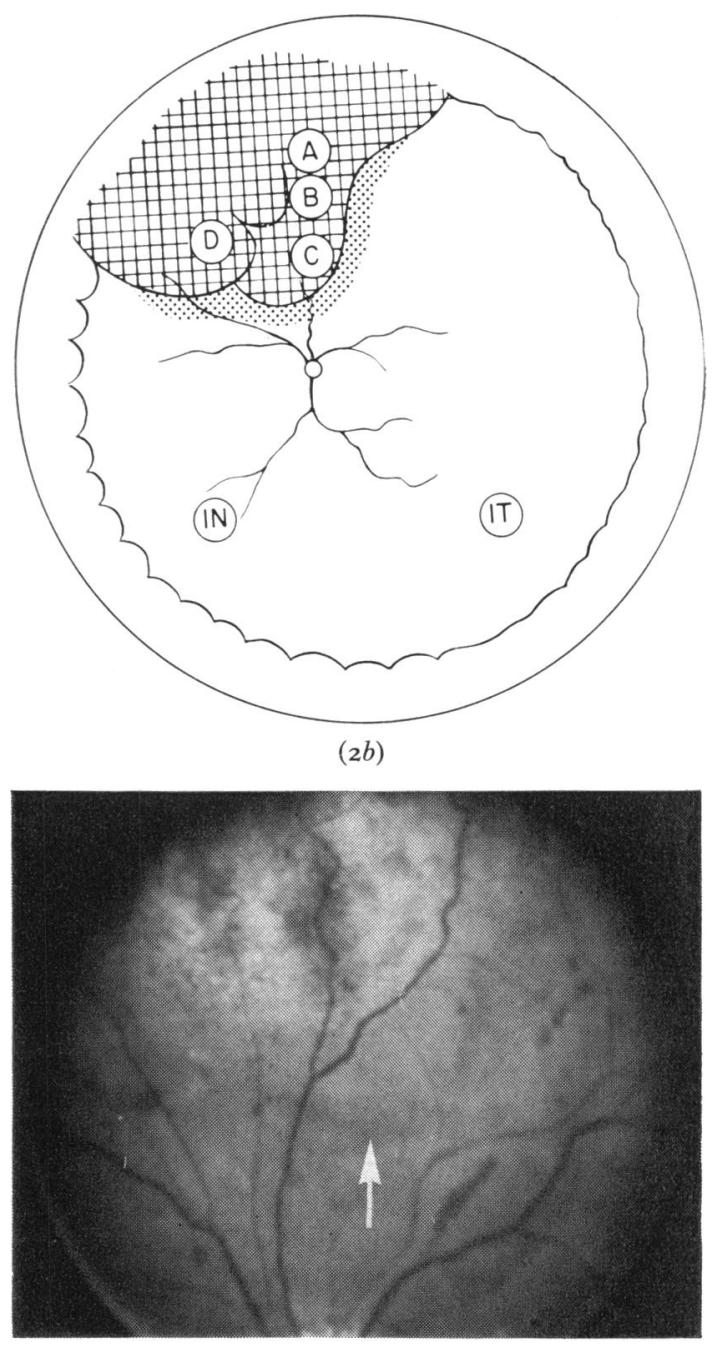

$(2 c)$

detachment requires precise localization of retinal defects to the scleral surface. The instruments must be in proper working order, and before each test, a new voltage plateau should be determined for the radioactivity electron probe and scaler.

The two cases with false-negative results reported herein emphasize the fact that a properly performed ${ }^{32} \mathrm{P}$ test cannot be wholly relied on to make the diagnosis of malignancy. In Case I, important factors that may have been responsible for the low radioactive counts were the haemorrhagic choroidal detachment located under the tumour and the necrosis within the tumour itself. The increased thickness of the tissue, which increased the tumour detector distance, may have been sufficient to reduce significantly the amount of radiation reaching the counting window. Also, the delay of six days 
from the time of ${ }^{32} \mathrm{P}$ administration to the time of testing may have been excessive, allowing significant radioactive decay.

In Case 2, we have no totally satisfactory explanation for the results being negative when the test was initially performed. Haemorrhage was not present, and the interval between administration of the radioactive phosphorus and the testing was 48 hours. Although the phosphorus may not have been absorbed from the gastrointestinal tract, administration in all our cases has been done under supervision, and patients have been given the radioactive phosphorus on an empty stomach with specific instructions to avoid ingesting antacids the day that the ${ }^{32} \mathrm{P}$ is given, since compounds such as aluminium hydroxide gel can bind phosphorus (Albright and Reifenstein, 1948). However, the negative test results may have accurately reflected a period of minimal metabolic activity within the tumour, because eight months later when the test results were strongly positive, there was unequivocal evidence of growth. In an effort to eliminate the uncertainties of ${ }^{32} \mathrm{P}$ absorption after oral administration, we currently administer the ${ }^{32} \mathrm{P}$ intravenously.

Our experience with these two cases, and that of Shields and others (1974), show that falsenegative results can be recorded over lesions that later are. verified as malignant melanomas. False-positive tests are also known to occur. Jarrett and Hagler (1972) reported a false-positive result of a ${ }^{32} \mathrm{P}$ test over a benign adenoma of the pigment epithelium. Metastatic lesions also generally produce a positive ${ }^{32} \mathrm{P}$ test, and whereas choroidal haemangioma can generally be differentiated from melanoma by a negative ${ }^{32} \mathrm{P}$ test result (Jarrett, Hagler, LaRose, and Shields (I975) reported no false-positive results in 29 cases) Cox (I975) recently reported three cases in which the ${ }^{32} \mathrm{P}$ test result was positive.

While the potential merits of the ${ }^{32} \mathrm{P}$ test should be considered in reducing the possibility of misdiagnosis, the relative safety of the testing procedure itself should also be considered. Seven hundred and fifty microcuries of radioactive phosphorus produce only a small dose of radiation, considering the short half-life (I4 days) and the shallow tissue penetration of beta-rays (International Commission on Radiological Protection, 1970). It is about one-quarter to one-fifth the initial therapeutic dose used for the treatment of polycythaemia (Wasserman, 1976), and while the absorbed dose from $750 \mu \mathrm{Ci}$ of ${ }^{32} \mathrm{P}$ in 'standard man' is approximately 28.5 rads (International Commission on Radiological Protection, 1970), information available from the National Council on Radiation Protection and Measurements suggests that the long-term radiation risk relative to development of leukaemia and other malignancies is probably only slightly raised (National Council on Radiation Protection and Measurements, I97I). Even with repeated administration of ${ }^{32} \mathrm{P}$ for polycythaemia, haematological toxicity is usually minimal, if it occurs at all, and other complications caused by radiophosphorus are most unusual (Wasserman, 1976).

One must also consider whether the performance of the ${ }^{32} \mathrm{P}$ test in any way influences the incidence of delayed tumour metastasis. This will probably never be known because the tumour itself is so capricious, in regard to its local behaviour and to its metastasis to distant sites. Nevertheless, the ${ }^{32} \mathrm{P}$ testing procedure is accompanied by significant manipulation both in the manoeuvre associated with tumour localization and in that associated with the actual radioactive counting. Posteriorly placed probes for posteriorly located lesions may in some instances disrupt the small ciliary vessels leading to the choroid.

We have observed bleeding into and under malignant melanomas during the localizing step and are aware that others have experienced similar complications. Although there generally is no urgency in enucleating an eye with malignant melanoma, once the episcleral tissue has been disturbed, and particularly if some of the posterior ciliary vessels are injured, prompt definitive treatment would seem desirable.

While the properly performed ${ }^{32} \mathrm{P}$ test is a valuable test for determining malignancy of the posterior globe, we must guard against the tendency to underemphasize experienced clinical judgement. Whereas the ${ }^{32} \mathrm{P}$ test may in some instances prove to be more reliable than the examiners in predicting malignancy (Shields, Hagler, Federman, Jarrett, and Carmichael, 1975), the reverse may also be true, as demonstrated by Shields and others (1974) and the cases reviewed here. In such cases, clinical judgements have been superior to the ${ }^{32} \mathrm{P}$ test. The ${ }^{32} \mathrm{P}$ test must be considered in proper perspective, with the understanding that it is a laboratory test with the potential for both false-positive and falsenegative results. We do not use ${ }^{32} \mathrm{P}$ testing on all eyes suspected of harbouring melanoma because in many instances the tumour is considered sufficiently characteristic that a proper diagnosis can be made without invasive techniques. We do believe, however, that it is indispensable that at least two experienced examiners should evaluate a suspicious lesion. If enough uncertainties about the diagnosis persist, the lesion may be considered then for ${ }^{32} \mathrm{P}$ testing or, alternatively, its growth can be watched with careful clinical drawings or photographs and considered for ${ }^{32} \mathrm{P}$ testing later. In rare instances, a diagnostic trial of irradiation may be considered if there is a strong possibility that the tumour is metastatic. Until a more satisfactory, non-invasive, 
equally reliable, and practical test becomes available for determining malignancy, however, we anticipate that the ${ }^{32} \mathrm{P}$ test will continue to be valuable as a diagnostic aid in the differential diagnosis of lesions in the eye.

\section{Summary}

Two false-negative results from ${ }^{32} \mathrm{P}$ testing for histologically verified malignant melanomas of the choroid are reported. In the first case, a haemorrhagic choroidal detachment caused an increase in the distance between the tumour and the counting probe; additionally, the tumour was necrotic. Both factors are likely to have contributed to the falsenegative result. A satisfactory explanation for the false-negative result in the second case was not determined, although it may have accurately reflected a period of minimal tumour activity, inasmuch as repeat ${ }^{32} \mathrm{P}$ testing was strongly positive eight months later, when unequivocal evidence of tumour growth was present. An alternative explanation is that the orally administered ${ }^{32} \mathrm{P}$ was incompletely absorbed.

Since ${ }^{32} \mathrm{P}$ testing is frequently accompanied by significant manipulation both in the manoeuvre associated with tumour localization and in that associated with the actual radioactive counting, it would seem desirable to perform indicated enucleation immediately after completion of the ${ }^{32} \mathrm{P}$ testing.

While the properly performed ${ }^{32} \mathrm{P}$ test remains a valuable diagnostic test for helping to establish the presence or absence of malignancies of the posterior globe, it is important to guard against the tendency to underestimate careful clinical evaluation.

\section{References}

Albright, F., and reifenstein, E. C., JR. (1948) 'The Parathyroid Glands and Metabolic Bone Disease:

Selected Studies', p. 38. Williams \& Wilkins, Baltimore

cox, M. S. (1975) Trans. Amer. Acad. Ophthal. Otolaryng., 79, 307

GASS, J. D. M. (1966) Arch. Ophthal., 76, 700

INTERNATIONAL COMMission ON RADIOLOGICAL PRotection (i970) 'Protection of the Patient in Radionuclide

Investigations'. ICRP Publication I7. Pergamon, Oxford

JARRETT, W. H., II, and HAGLER, W. s. (1972) Arch. Ophthal., 88, 695

—, HAGLER, W. S., LAROSE, J. H., and SHIEldS, J. A. (1975) 'Clinical experience with presumed hemangioma of

the choroid: radioactive phosphorus (32-P) uptake studies as an aid in differential diagnosis'. Read at the meeting

of the American Academy of Ophthalmology and Otolaryngology, Dallas, 24 September

NATIONAL COUNCIL ON RADIATION PROTECTION AND MEASUREMENTS (197I) 'Basic Radiation Protection Criteria'.

NCRP Report 39

RUIz, R. s. (1972) Trans. Amer. Acad. Ophthal. Otolaryng., 76, 535

, and HOWERTON, E. E., JR. (1975) Ibid., 79, 287

SHIELDS, J. A., HAGLER, W. S., FEDERMAN, J. L., JARRETT, W. H., II, and CARMICHAEL, P. L. (I975) Ibid., 79, 297

—, SARIN, L. K., FEDERMAN, J. L., MENSHEHA-MANHART, O., and CARMiChaEl, P. L. (1974) Ophthal. Surg., 5, I3

WASSERMan, L. R. (1976) Semin. Hematol., 13, 57 